\title{
Cation Exchange Behavior of Lanthanides and Trivalent Actinides in Ethanol-Hydrochloric Acid
}

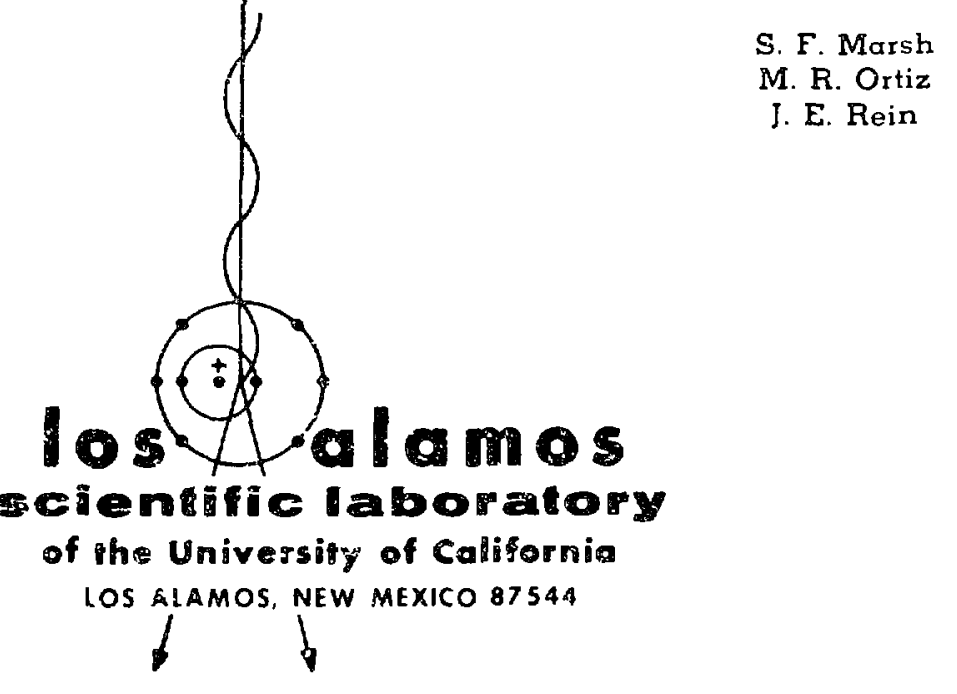

by

S. F. Marsh

M. R. Ortiz

J. E. Rein 
This work was supported by the Fuels and Materials Branch of the U.S. Atomic Energy Commission's Division of Reactor Research and Development.

Printed in the Unitod Stares of America. Available from Nathonal Tochnical information Service

U.S. Dopartment of Commerco

5285 Port Royal Road Springtiald, VA 2215!

Price: Prinlod Copy \$4.00 Microtiche \$2.25

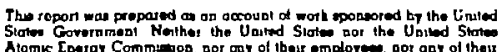

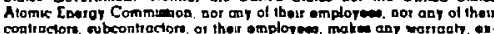

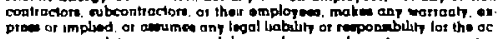




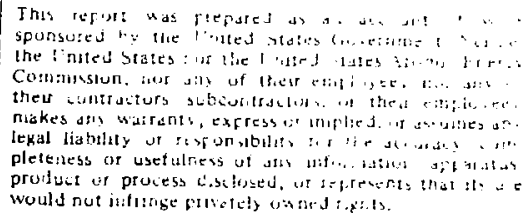

\title{
CATION EXCHANGE BEHAVIOR OF LANTHANIDES AND TRIVALENT ACTINIDES IN ETHANOI-HYDROCHLORIC ACID
}

by

\author{
S. F. Marsh, M. R. Ortiz, and J. E. Rein
}

\begin{abstract}
Cation exchange in various organic solvent-hydrochloric acid media was studied for separating microgram levels of fission products from trivclent actinides. Ethanol provided the largest yroup separation factors. With either conventional or macroporous resins, equilibrations were too slow for useful column operation. The slow equilibration was caused by slow diffusion of the inorganic ions within the resin beads. A pellicular ion exchange resin, consisting of silica beads with a thin shell of resirn, gave rapid and complete lanthanide-trivalent actinide separations.
\end{abstract}

\section{SUMMARY}

A cation exchange separation system was developed for the trivalent actinide and lanthanide groups. This separation is based on the formation of stronger trivalent actinicle chloride complexes. This procedure combines an aqueous-organic mixed sol. vent, which is high in both ethanol and hydrogen chloride, and a pellicular ion exchange resin

We evaluated various solvent compositions and ion exchange resins using europium and americium tracers to repre: ant the two elemental groups. The largest distributior coefficient (Kd) differences were obtained when using ethanol as the organic component. Furthermore, the Eu Am Kd ratios increased with increasing concentrations of both ethonol and hydrogen chloride. However, equilibration of the chloride complexes between the solvent and the resin was too slow in high ethanol to be useful with columns of microporous (conventional) or macroporous resin. Rapid equilibration was attained with pellicular cation exchange resin thai consisted of solid silica beads coated with a thin layer of resin

An effective separation uses $10 \%$ aqueous. ethanol-7.6.1/ $\mathrm{HCl}$ to elule trivalent actinides from a column of pellicular cation exchange resin. The lanthanides are then eluted with $5.1 / \mathrm{HCl}$, which is tree of organic complexants or salts that usually in- terfere in chemical assays. This separation will be in corporated into a procedure used to determine bur. nup in fast breeder reactor (FBR) fuels, using the tission product lanthanide group as the burnup monitor

\section{INTROUUCTION}

Early investigations revealed similarities and regularities in the chemical and physical properties of transplutonium elements and the lanthanide elements, thus confirming an inner transition of the $5 f$ electrons analognus to the $4 \mathrm{f}$ electron transitions of the lanthanides. Because the stable oxidation state of most transplutonium elements, like the lanthanides, is +3 makes their mutual group separation difficult. Group separations have been achieved by various ion exchange and solvent extraction systems, mainly by incorporating organic complexants ${ }^{1,2}$ or high concentrations of dissolved inoryanic salts of a com. plexing anion ${ }^{3.4}$

When the objective of the separation is to obtain fractions for subsequent chemical assay, complexants or inorgenic salts thut invariably interfere in assay methods must first be destroyed or removed. ine complexants are destroyed by rather harsh treatments, such as wet ashing or combustion. The 
extent of the treatment depends on the stability of the particulat compound. Equally tedious treatments aze often sequired to remove brge amounls of inorganic salts Cation exchange in hydrochloric acid medic 5 is especialiy attractive because chloride is not a strong. ly interfering complexint in assay methods and can be removed, if desired by simple volatilization. Figure I shows that the Kd value for -3 lanthanides. represented by the extreme group members lanthanum and leutetium, becones minimum near $5.1 / \mathrm{HCl}$, and theredter increases with inctersing hydrochloric acid concentzation. However, the Kd value for the irivalent actinides, represented by $\mathrm{Am}^{3}$. rontinuously decreases with increasing hydrochloric acid concentration.

This tendency of invalent actindes to form stronger chlonde ansonc complexes was used by Dicrnond and coworkers ${ }^{6}$ in 1952 to separate recently discovered americium from neutron-irsadiated plutonium samples A useful sepatation of rericium from lanthande fission products was at. haned using Dowex 50 crition exchange resin (of undestunated cross-linkage) in aqueous $131 / \mathrm{HCl}$. which was prepared by soturating concentrated hydrochloric acid with hydrogen chloride gas these sime authors improved the seporction by using a $20^{\circ}$ ethanol solution saturated with hydrogen

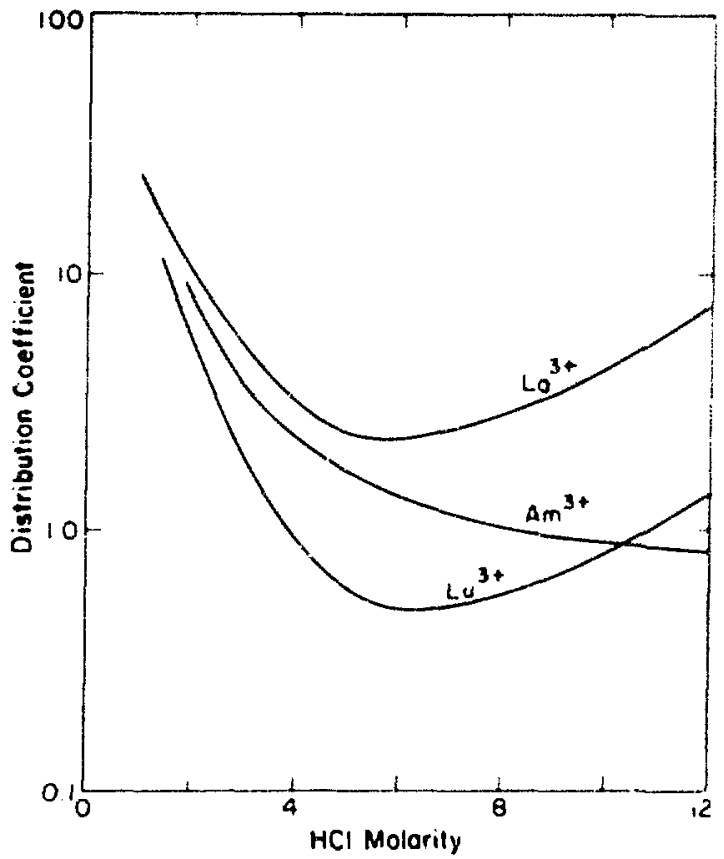

Fig. 1.

Serposion of hamhanum, leuteritum. and americium on cation exchange resin from aqueoses $\mathrm{HCl}$. chlonde (Fig 2) In the two decades since this work. mony applicethons of the $20^{\circ}$ o ethernol hydrechlonc acd systom have been reyorted an the bitertuze. Sutrrsungly, we lound no reterences extending the system to hugher ethomol and higher hydrochlon arat concentemons at the thrte we began out in vestigcitons Aussurn investigcters ${ }^{7}$ recently

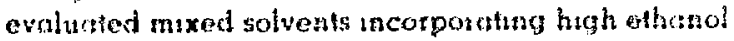
and high Aydroctlone and concentrations

We requated a lantomdetruclent actisude group

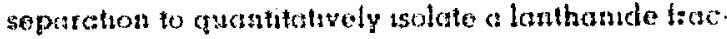
thon that will serve as the fission montor an a thomeal method to deternane busmup in maxed urctnum -plutontutn FBR fucts For this applicstion the kathande fraction must be (1) essentially tree of other elenents, especially the twatent sctindes thet are paticulatly abundant in uradiated PBA fuel, and (2) in a medium itee of complexants ot salts that woyld untertere with chemical assay methods

\section{EXPEPIMENTAL AND DISCUSSION}

\section{A. Selection of Elhenol for the Mixed Solvert}

We hist evalucied mixed solvents contonnang acetone, methanol, ethonol, n-propanol, and

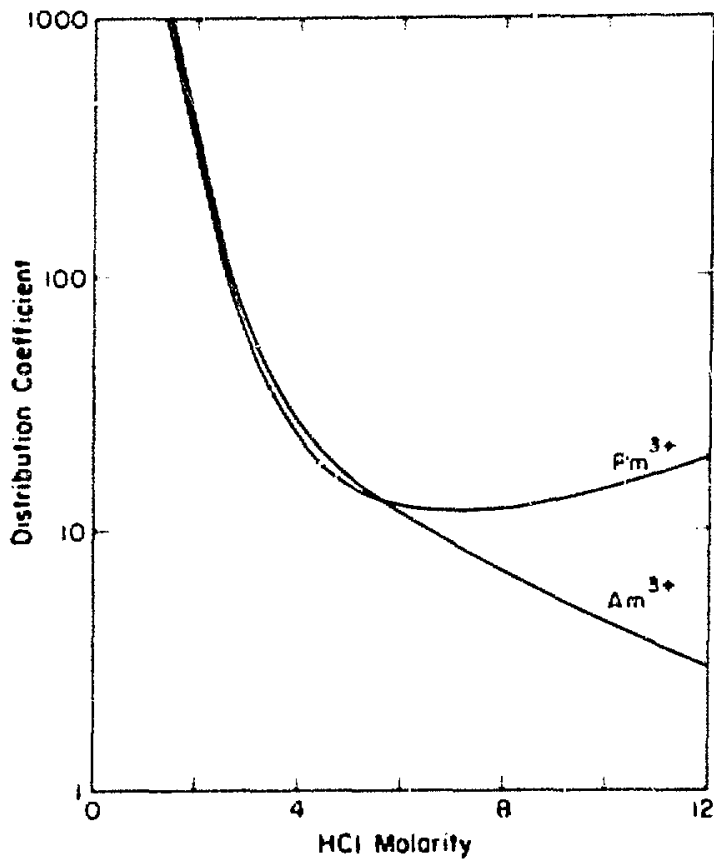

Fig. :

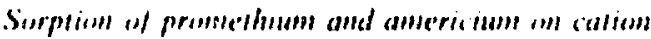

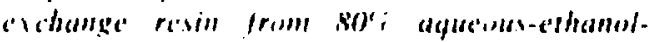

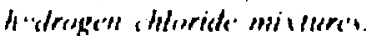


1sopropunol. with the aqueous portion tanging trom 50 to $90^{\circ} \circ$." Tor the group separanon of lanthandes and truvalent acunides using conventional, macroporous cation exchange resin. The intial ex. periments unvolved balch contacts of snany mixad solvent combunctions with AGSOW.XA catson ex. change resin using radiotrecers of ${ }^{152} 154 \mathrm{Eu}$ and 241 Am under essentially static conditions. II was later determined that equilibrium was rot attoined under these neas-static conditions, nonetheless, usedul trend intormation was oblained indicating that ethonol gave the largest $\mathrm{E}_{\mathrm{u}}$. Am Kd differences of any otganic solvent and that this difference in. creased with increasing ethanol content. We theretore selected ethanol for further investigation.

\section{B. Evaluation of Aqueous-Ethanol-Hydrogen Chlorido Mixed Solvent Composition and Ion Exchange Resin Properties}

Values of $\mathrm{Kd}$ lot europium and amencium were measured lot various aqueous-ethanol-hydtogen chloride compositions using a conventional microporous cotion exchunge resin (AG5OW.X4)

The experments involved 18.h batct erntacts with vigorous mechanical agitation, a $10 \cdot \mathrm{ml}$ liquid volume, and $0 \perp g$ of dried ressn

The definition of $\mathrm{Kd}$ as used in thus report is

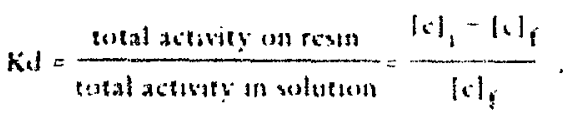

- Becouse the composition of mixed solvents may be expressed in masy ways, the opporlunaty for ambiguly 2 great The formot used in this report is " $\mathrm{X}$ " $\mathrm{O}_{0}$ cqueons-organic solvent. " $\mathrm{Y}$ " $\mathrm{HCl}$ " $\mathrm{X}$ " millihters of $12.1 / \mathrm{HCl}$ is added to a 100 mi volumetsic flask The organic solvent is added to the volume mork. waiting for temperature equihbration belore fincl volume adiustment A meosured volume of this muxture is transterred to a larger flask (dissolution of hydrogen chloride substantially increases the solu. ton volume), and the hydrochlonc acid concentre. tion is uncreased by bubbling hydrogen chloride into the soiution, whle cooling in an ice buth. until the approximate " $\mathrm{Y}$ " $\mathrm{HCl}$ molarty is reached The actual hydrochloric acid concentration is determuned by titration with stondard sodium hydroxide to a phenolphthalein end point. where

$|c|$ : Initicl concentration of rudiut, i. it. solution, and

$|c|$ tinal concentration of sesdrot........ solution

The Kai values colculcted by this rell. : : : about 100 times smaller thar would $x \in$ s. $: 1, \ldots$.

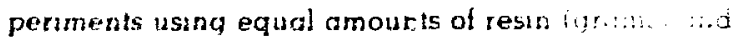
solvernt (milliliters)

Fiqure 3 shows the measured $K d \quad, \ldots$ : eurupum and amerscium and thell st...: : : :

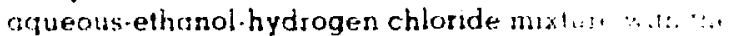

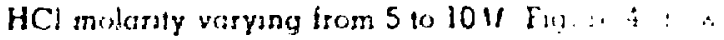

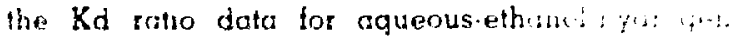
ch.onde composstions with vorying levels : ! : : $\mathrm{HCl}$ molarity and the aqueous-ethams . . I. . ... : The value of the Eu Am Kd ratue is st.... : dependent on both the $\mathrm{HCl}$ rolunt? $\therefore, \cdots$ uq. exus.ethanol composituon, attaming : ......... value of aboul 100 tor $9.14 \mathrm{HCl}$ over the t...:? : " $25^{\circ}$ o aqueous composition

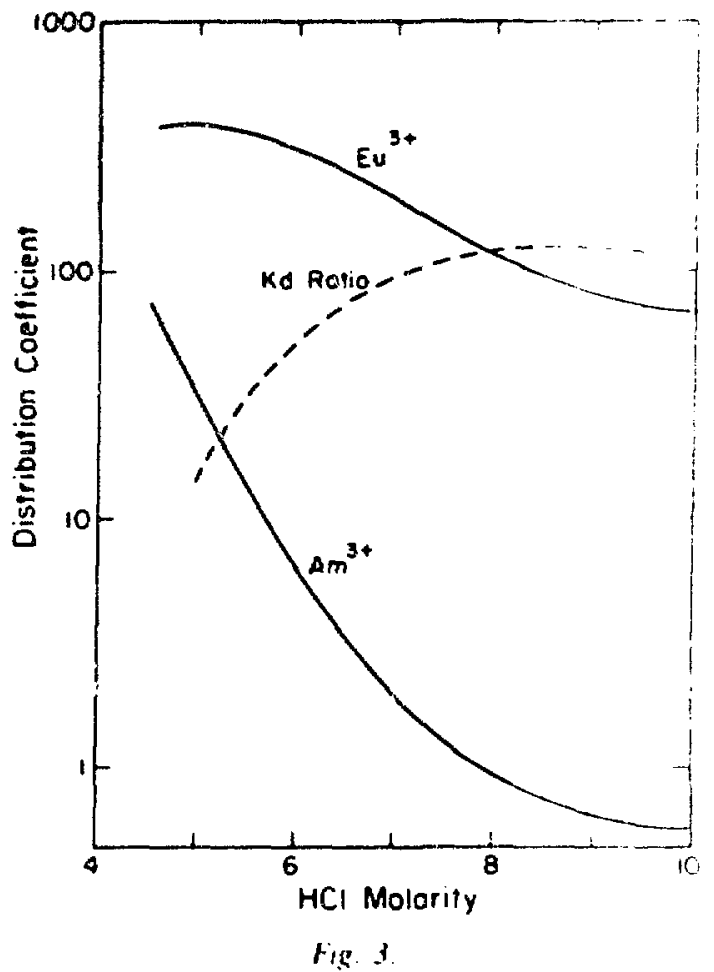

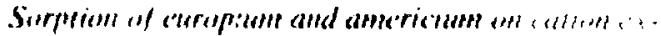

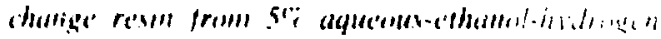
chloride meiviures. 


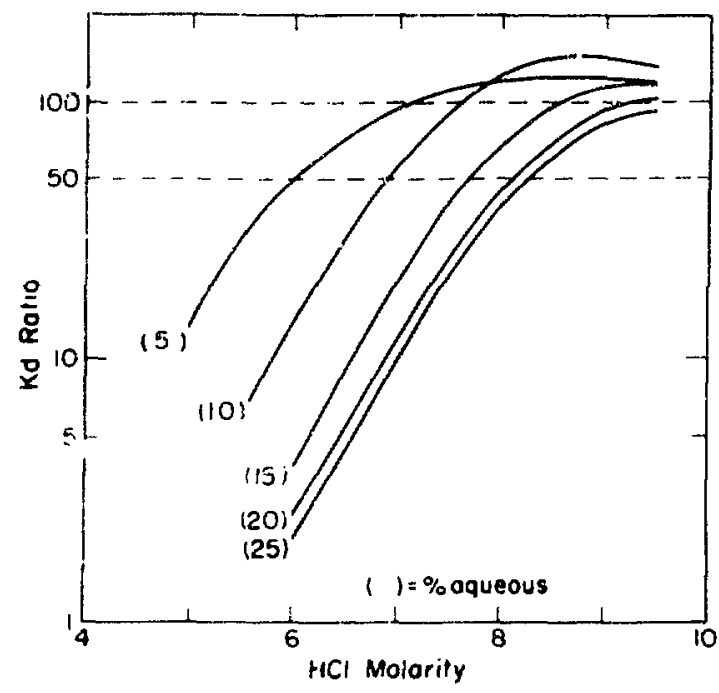

fig. 4

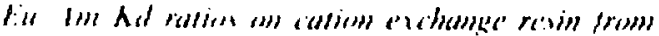

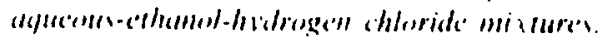

This rela'ively large $\mathrm{Kd}$ ratio indicated that a column of the microporous resin would retain only the rare earth fraction, thereby providing an effectwe group separation. This did not happen. Not only was the separation inadequate, but neither europium nor amencium could be completely eluted. The elution behavior was as if two different complex species of each element were present, one eluting in a normal manner and the other eluting at a much slower rate In an attempt to explain this unusual behavior, the elution of europium was measured trom columns containing three ( $2 \mathrm{X}, 8 \mathrm{X}$, and $12 \mathrm{X}$ ) cross-linked caton exchange resins with $5 \%$ aqueous-ethanol- $8.5 \mathrm{M}$ $\mathrm{HCl}$ mixed solvent. Table I shows that the initial elution rate is slower and that the later elution rate is faster for low cross-linked resin. A plausible explanation is that the more open structure of low crosslinked resin provides laster equilibrction, hence both fuster sorption and desorplion rates.

Reaction rates between inorganic ions and ion exchange resin often are decreased in mixed solvents due to higher solvent viscosity and reduced resin pore size caused by bead swelling. A macroporous cation exchange resin, AGMP.50, with its larger pores and increased surtace area, was therefore evaluated. The column elution behavior for americium using $15 \%$ aqueous-ethanol-8.6M $\mathrm{HCl}$, (Fig. 5), showed little improvement when compared with the conventional resin. We conducted an experiment with this resin to measure the sorption of e:iropium as a function of time for three solvent compositions with the aqueous content ranging from 40 to

TABLE I

\section{CROSS-LINKAGE EFFECT ON ELUTION OF EUROPIUM FROM AG5OW CATION EXCHANGE RESIN (50-100 MESI)}

\begin{tabular}{c}
$\begin{array}{c}\text { Eftluent } \\
\text { Increment } \\
\text { (ml) }\end{array}$ \\
\hline \\
1 \\
2 \\
3 \\
4 \\
5 \\
6 \\
7 \\
8 \\
9 \\
10
\end{tabular}

Totals

\begin{tabular}{|c|c|c|}
\hline \multicolumn{3}{|c|}{$\begin{array}{l}\text { Percent of Europium } \\
\text { Eluted in Increment }\end{array}$} \\
\hline $2 x$ & $8 X$ & $12 x$ \\
\hline 9.8 & 17.1 & 34.6 \\
\hline 8.1 & 9.5 & 10.2 \\
\hline 6.8 & 6.4 & 5.7 \\
\hline 5.6 & 5.3 & 40 \\
\hline 4.6 & 4.0 & 3.1 \\
\hline 3.8 & 3.2 & 2.5 \\
\hline 3.3 & 2.7 & 2.1 \\
\hline 2.8 & 2.3 & 1.8 \\
\hline 2.7 & 2.1 & 1.5 \\
\hline 2.3 & 1.8 & 1.3 \\
\hline 49.8 & 54.4 & 66.8 \\
\hline
\end{tabular}

$100 \%$. The experiment involved a series of batch contacts using vigorous mechanical agitation and ${ }^{352.154} \mathrm{Eu}$ as the tracer. Aliquois of the supernatant liquid were withdrawn periodically and the ${ }^{152,154} \mathrm{Eu}$

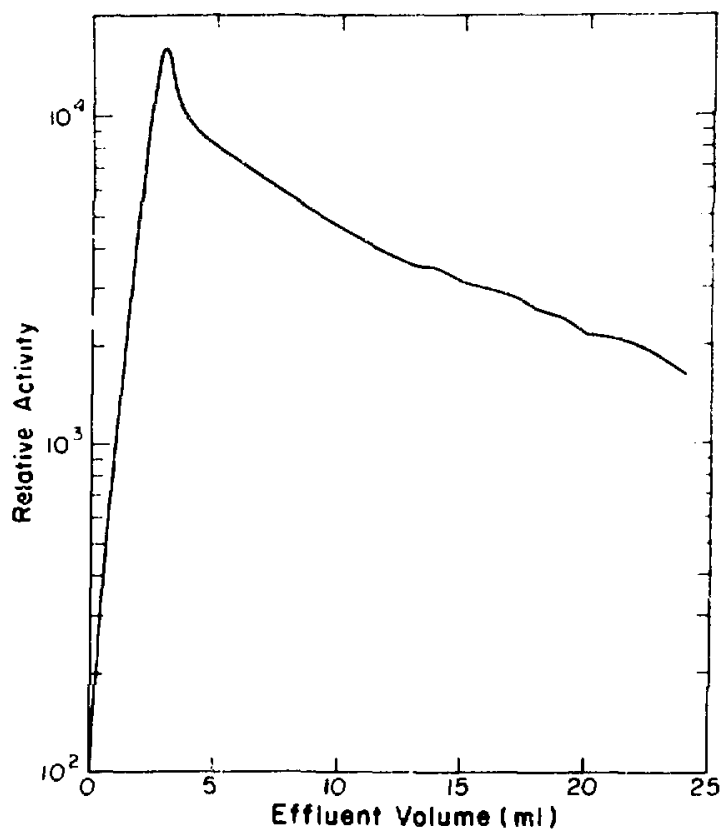

Fig. 5.

filution of americium from a column of macropormes atom exchange resin with 15\% anterenc-athanol-8.6M HCl. 
activity measured. Figure 6 shows that equilibrium was attained within $15 \mathrm{~min}$ for $100 \%$ aqueous $-12 \mathrm{M}$ $\mathrm{HCl}$, but was not attained in $22 \mathrm{~h}$ with either $60 \%$ aqueous-ethanol-10.7M HCl or $40 \%$ aqueousethanol-9.8 in $\mathrm{HCl}$.

We evaluated the effect of the macroporous resin mesh size on $\mathrm{Kd}$ using a $5 \%$ aqueous-ethanol-8.4M $\mathrm{HCl}$ mixed solvent and both 152,154 Eu and ${ }^{241} \mathrm{Am}$ tracers. Figure 7 shows that the sorption of europium increased with decreasing mesh size, whereas the sorption of americium remained nearly constant. This indicates a trend toward larger group separa. tion factors for the lanthanides and trivalent actinides with finer mesh resin.

\section{Successful Application of Pellicular Ion Ex- change Resin}

Our miror conclusion from the above results is that an effective ion exchange separation of the lanthonide and trivalent actinide groups, using the aqueous-ethanol-hydrogen chloride system, requires a cotion exchinge resin where the exchange reaction is limited io the bead surfece. Pellicular ion exchange resin, whirh was developed for high. pressure liquic chromatography. is such a resin. Eirch bead of thi: resin is a solid silica sphere of about $40 . \mu \mathrm{m}$ diam, coated with a $1-102-\mu \mathrm{m}$ layer of ion ex. shange resin. Batch-contact experiments, similar to those done with the macroporous resin, were con-

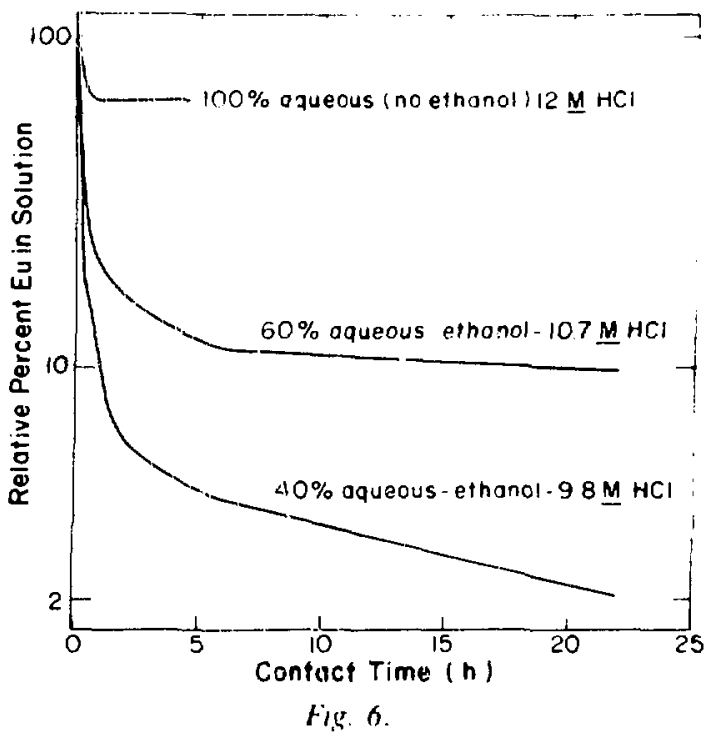

Elfect of ethamol on earonjum esulihration with macroporous cation evchange resin from acukerus. ethanol-hydrogedl chloride' misatures.

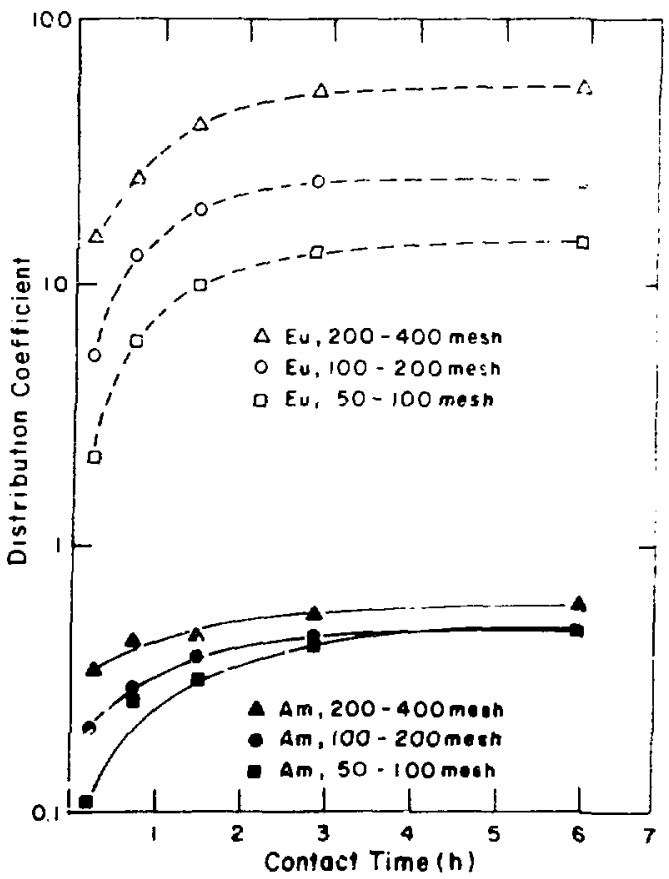

Fig. ?

Equilithatiom of couropium and an!ericium with

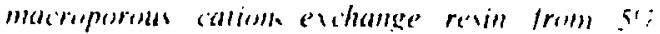

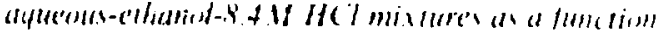
11) rain bewh ias

ducled for a pellicular cation exci.ange resin * Equilibrcition was attained within $15 \mathrm{~min}$ for a $10^{\circ}$ 。 aquesus-ethanol-8.6.1/ $\mathrm{HCl}$ medium (Fig. 8), contrasted to more than $22 \mathrm{~h}$ for the macroporous resin with a mixed solvent of even lower ethanol content of $60^{\circ}$ o aqlisnis-ethanol-10.71/ HCl (Fig. 6)

The small bead size of the pellicular resin, however, resulted in a very slow flow rate, even in shori columns. Flow rate was increased to a sctisfactory level of $0.12 \mathrm{ml} \mathrm{min} \mathrm{for} \mathrm{a} 6 \cdot \mathrm{mm}-\mathrm{id}$. by $20 \cdot \mathrm{mm}$ resin bed by applying a slight positive air pressure of 0034 utm $(0.5 \mathrm{psi})$ to the column. The column design in Fia 9 includes a solvent reservoir and a convenient connection for the air pressure line. Figure 10 shows the separation of europium and americium using this column. Americium is $-99^{\circ}$ o eluted with 5 $\mathrm{ml}$ of $10^{\circ}$ orqueous ethanol-7.5.1/ $\mathrm{HCl}$ with no elution of europium. Europium then is completely eluted with $5 \mathrm{ml}$ of aqueous $5.1 / \mathrm{HCl}$.

An adeciuate separation of americium from as much as $210 \mu \mathrm{g}$ of fission-product-distributed lanthanides wos obtained on the 6. by $20 \mathrm{~mm}$ resin bed columu shown in Fig. 9. This quantity of

"HC-Pellionex-SCX, H. Reeve Angel and Company 


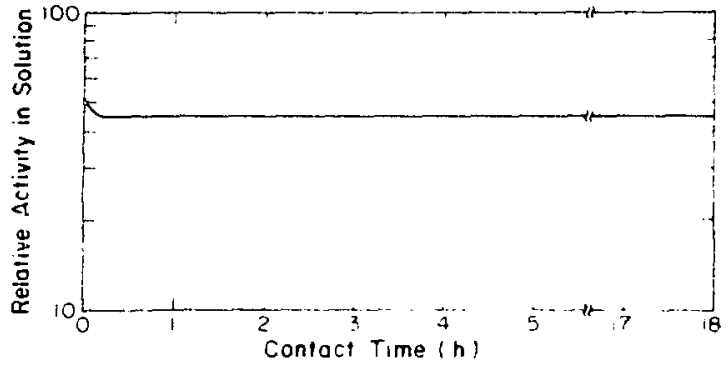

Fig. 8 .

Equilibratian of eturopitum on pellicular cation ex-

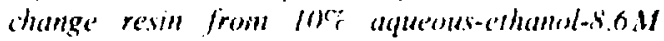
HIC

lanthanides represents a thirtyfold excess over the amount needed for the intended burnup determina. tion.

Pellicular resins were observed in our laboratory and elsewhere ${ }^{B}$ to undergo physical degradation of the ion exchange surface, particularly in corrosive solvents such as ethanol-hydrochloric acid mixtures. Nonetheless, we have satisfactorily reused pellicular resin up to ten times, which tends to offset the current high cost of nearly $\$ 10 / \mathrm{g}$.

After we completed this work, an English translation of a paper by Guseva and Tikhomirova ${ }^{7}$ reported studies with mixed solvents of methanolhydrochloric acid and ethanol-hydrochloric acid for lanthanide-trivalent actinide separations with conventional cation exchange resin. Similar to our findings, equilibration rates were observed to be unacceptably slow for high alcohol-content solvents. At equal percentage, methanol gave faster equilibration than did ethanol, and the recommerded solvent for the separation was $40 \%$ aqueous-methanol- $8 \mathrm{M}$ $\mathrm{HCl}$. Because this conflicted with our finding that ethanol-containing solvents give superior separations, the use of methanol was reevaluated for conventional cation exchange. Figure 11 shows that the maximum Eu/Am Kd ratio was only 16, about one-seventh that obtained with ethanol mixed

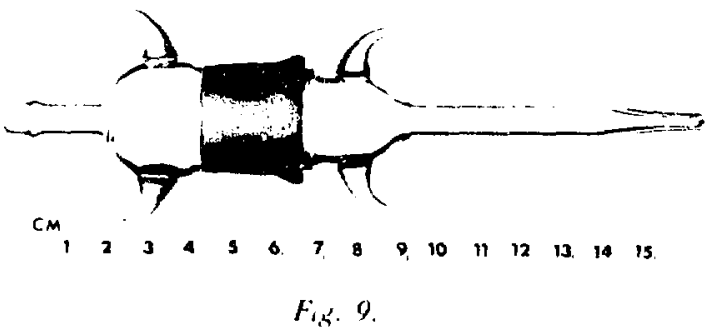

Pressurized ion exchange coltum! used with pellicular resin.

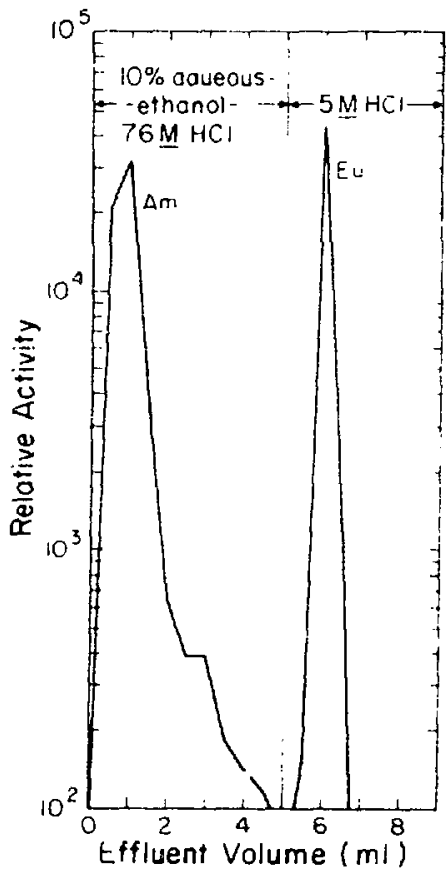

Fig. 10.

Separation of americium and cueropium on a callumen of pellicular cation exchange resin.

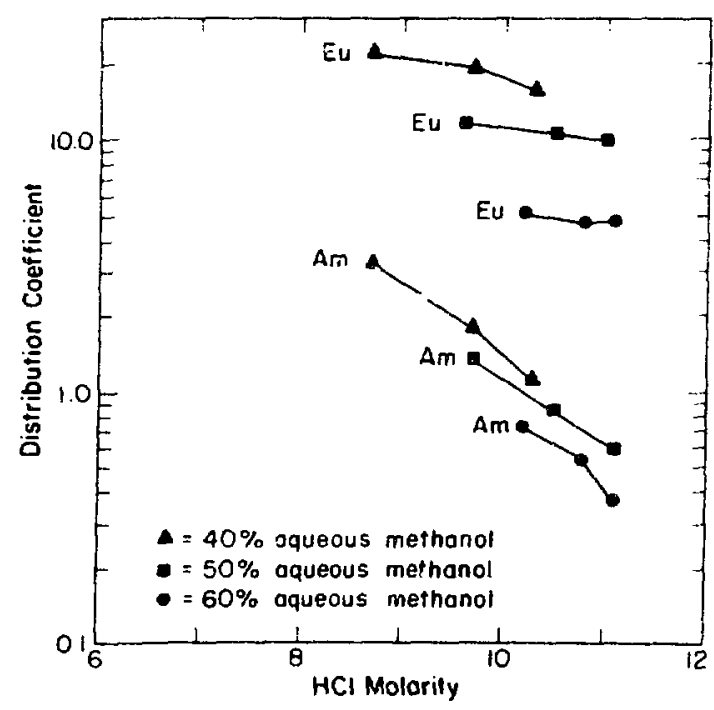

Fig. 11 .

Sorption of europium and americium on comventiomal cation exchange resin from aqueosusmethans-hydrogen chloride mixtures. 
solvents (Fig. 3). This does not imply that methanolhydrochloric acid solvents do not provide taster equilibrations in combination with conventional ion exchange resin, but it does justify our selection of ethanol-hydrochloric acid solvents in combination with pellicular ion exchange resin.

\section{CONCLUSIONS}

The lanthanide and trivalent actinide groups show large differences in their affinity for cation exchange resin from aqueous-ethanol-hydrogen chloride solvents. The normally slow equilibration of cations between resin and high organic content mixed solvent becomes rapid when pellicular ion exchange resin is substituted for conventional resin. Effective group separations can be achieved within a wide range of aqueous-ethanol-hydrogen chloride com. pusitions The separation system was demonstrated by selectively eluting trivalent actinides from a column of pellicular cation exchange resin while retrining the lanthanides; the lanthanides were then eluted with $5.1 / \mathrm{HCl}$. This separation, which provides a lanthanide solution Iree of organic complexants or salts, is being incorporated into a method to determine nuclear fuel burnup using the fission product lanthanide group as the burnup monitor.

\section{ACKNOWLEDGMENTS}

We gratefully acknowledge the gereral consultr. tion of Professor Roy D. Caton, University of New Mexico, and the specific suggestion of Professor Hurnld F. Walton, University of Colorado, that pellicular resin be investigated.

\section{REFERENCES}

1 R. D. Baybarz and B. Weaver, "Separation of Transplutoniums and Lanthanides by Terticry Amine Extractions," Oak Midge National Laboratory report ORNL-3185 (December 1961).

2. B. Weaver and F. A. Kapplemar. "TALSPEAK: A New Method of Separating Americium and Curium from an Aqueous Solution of an Aminopolyacetic Acid Complex with a Monoacidic Organophosphate or Phosphonate," Oak Ridge National Laboratory report ORNL-3559 (August 1964).

3. M. H. Lloyd and R. E. Leuze, "Anion Exchange of Trivalent Actinides and Lanthanides," Nucl Sci. Eng. 11, 274-277 (1961)

4. F. L. Moore, "New Approach to Separation of Trivalent Actinide Elements from Lanthanide Elements; Selective Liquid-Liquid Extraction with Tiicaprylmethylammonium Thiocyanate," Anal. Chem. 36, 2158-2162 (1964).

5. K. Street, Jr., and G. T. Seaborg, "The Separa. tion of Americium and Curium from Rare Earth Elements," J. Amer. Chem. Soc. 72, 2790-2792 (1950).

6. R. M. Diamond, K. Street, Ir., and G. T. Seaborg, "An Ion-Exchange Study of Possible Hybridized $5 f$ Bonding in the Actinides," J. Amer. Chem. Soc. 76. $1461-1469$ (1952).

7. L. I. Guseva and G. S. Tikhomirova, "Sorption of Certain iransplutonium and Rare Earth Elements from Concentrated Solutions of Hydrochloric Acid in the Presence of Alcohol on a Cation-Exchange Resin," Radiokhimiya 14, 188-193 (1972), (English translation by Consultants Bureau, pp. 197-201).

8. C. D. Scolt and N. E. Lee, "Use of Sequential Columns of Microreticular and Pellicular Ion Exchange Resins in the High-Resolution Separation of Complex Biochemical Mixtures," Oak Ridge National Laboratory report CONF-730509-1 (1973). 